\title{
China-Czech Relations from the Perspective of Chinese Foreign Policy in Central and Eastern Europe Under Xi Jinping
}

\author{
Siyang $\operatorname{Liu}^{1,2, *}$ \\ ${ }^{1}$ Department of International and Diplomatic Studies, Prague University of Economics and Business, 13067 \\ Praha 3, Czech Republic \\ ${ }^{2}$ Department of Social Science, Hebei GEO University, Shijiazhuang, Hebei 050031, China \\ *Corresponding author. Email: siyang.liu@vse.cz.
}

\begin{abstract}
China's economic rise and its increasing participation in international affairs have made China play an important role in contemporary international relations. Since President Xi Jinping took office, China has actively promoted major-country diplomacy with Chinese characteristics and adjusted its foreign policy. Among them, Cooperation between China and Central and Eastern European Countries (also known as "17 + 1" Cooperation) as an important part of China's overall cooperative diplomacy, as well as summit diplomacy, are bright spots in Xi's diplomacy in the region. In this context, the relations between the Czech Republic and China continue to advance. High-level visits between the two sides are frequent and a strategic partnership has been established; Pragmatic cooperation has become the main theme of the development of economic and trade relations between the two countries, with China becoming the Czech Republic's largest trading partner outside the EU and the Czech Republic becoming China's second-largest trading partner in Central and Eastern Europe. From a longterm perspective, it is a potential option for China-Czech relations to make full use of the " $17+1$ " Cooperation framework to gradually promote the development of the strategic partners between the two countries.
\end{abstract}

Keywords: "17+1" Cooperation, Summit Diplomacy, China Overall Cooperation Diplomacy.

\section{INTRODUCTION}

With China's economic rise and its increasing participation in international affairs, China plays an important role in contemporary international relations. Since Xi Jinping came to power, China has adjusted its foreign policy, actively promoted major-country diplomacy with Chinese characteristics, and built a global partnership network. As the largest developing country in the world, China has a time-honored historical partnership with the global South, especially in Africa and Latin America. But the relations between China and Central and Eastern European countries (hereinafter referred to as "CEEC") appear to have been ignored by international observers as a result of the post-cold-war economic restructuring of both sides. Although most CEEC had similar political backgrounds to China before the end of communism in the region, most of these ex-communist countries were more interested in returning to the West for political and political gain as communism collapsed in Eastern Europe. On the economic front, they are more focused on domestic transformation and do not see China as a long-term strategic partner. In recent years, the relations between China and CEEC have gradually recovered and the pace has been accelerated, especially after China launched the Cooperation between China and CEEC (also known as "17 + 1" Cooperation) in 2012, both China and CEEC have begun to recognize the value of more business-oriented linkages.

In this context, this paper takes China-Czech relations as an example and provides a reference for the analysis of relevant topics such as the change of relations between China and CEEC. In the paper, it reviews summit diplomacy and China's overall cooperative diplomacy (hereinafter referred to as "COCD"), which are the main content of China's 
diplomacy in Central and Eastern Europe. On this basis, it discusses the diplomatic and economic relations between CEEC under the "17+1" Cooperation initiated by China, explores the current situation and trend of China-Czech relations, and analyzes some obstacles and challenges that both sides need to be aware of in the near future.

In view of the increasing presence of China in Central and Eastern Europe, the ties are getting closer between China with CEEC. The pragmatic diplomacy Czech Republic in recent years and China's Summit Diplomacy and COCD in Central and Eastern Europe have formed a policy convergence. Against this background, what role does summit diplomacy play in the development of China-Czech Republic relations? How does the recent progress in cooperation between China and CEEC affect the relations between China and the Czech Republic? Through the continuous development of recent years, has the strategic partnership between the two countries been enriched, and what challenges does it face? This paper will analyze and explore these issues above, summarize the experience promptly, prevent and defuse risks. In the first part, based on introducing the progress and characteristics of summit diplomacy between China and CEEC in the new era, this part will mainly examine the changes in ChinaCzech relations from the perspective of summit diplomacy. In the second part, the new practice of China's diplomacy in Central and Eastern Europe in the new era is firstly introduced: China-CEEC "17+1" cooperation, which is a special case of COCD. Then it analyzes the influence of this cooperation framework on China and the Czech Republic. The third part objectively analyzes the shortcomings and uncertainties of these diplomatic explorations in the Central East and Europe and reflects on the challenges and risks it brings to the development of relations between China and The CEEC. This will help further develop the diplomatic relations between China and the Czech Republic and promote friendly exchanges between the two countries. It is of great significance to the development of relations between China and the Czech Republic and CEEC.

\section{CHINA AND THE CZECH REPUBLIC FROM THE PERSPECTIVE OF SUMMIT DIPLOMACY}

When discussing the changes in diplomatic actors since the $1960 \mathrm{~s}$, the British scholar R. P.
Barston pointed out straightforwardly that a distinctive feature of modern diplomacy is that the role of individual diplomacy of the head of state or government has been strengthened.[1] Indeed, although the history of summit diplomacy has a long history, it wasn't until the middle of the 20th century that the form of summit diplomacy in the modern sense was truly established, "and increasingly become a diplomatic style with strong vitality in contemporary diplomacy practice".[2] In recent decades, the advancement of science and technology and the development of the media industry have further created favorable conditions for the prosperity of summit diplomacy. Nowadays, summit diplomacy has become the normal and mainstream of diplomatic practice in various countries, and it has attracted the attention of domestic and foreign public opinion. Summit diplomacy is not only a diplomatic stage for the highest level of dialogue between countries but also an excellent opportunity to carry out important international and domestic publicity.

As China's economic and social life is increasingly integrated into the process of globalization, its international status and influence are on the rise, and its stakes in regional and global affairs are increasing. China's diplomacy is also actively adapting to the development trend of summit diplomacy. [3] In April 2012, Wen Jiabao, then Premier of The State Council of China, visited CEEC and attended the first Summit of China and 16 CEEC in Warsaw, Poland, marking that China and CEEC have entered a "new era of institutionalized cooperation". [4] Over the past eight years and more, the cooperation between China and the CEEC has achieved remarkable results and distinctive features, including regular summits at the prime minister's level. [5]

\subsection{Summit and Summit Diplomacy}

Summit diplomacy, as defined in the 2016 Edition of the Sage Handbook of Diplomacy, refers to "meetings of the highest political leaders"[6]. However, the connotation and extension of summit diplomacy are not as simple as the name implies.

The main body of summit diplomacy generally believes that when diplomacy exceeds the ministerial level and reaches the highest level, it is considered diplomacy at the summit. As far as the senior level is concerned, the term "summit" generally refers to the chief executive, including the chief of state and the head of government, but it can also be used in certain circumstances, which may 
include some other officials who are higher than the minister.[7] In other words, in addition to the heads of state or heads of government with statutory powers, the political leaders who actually master the diplomatic power are also the subjects of the summit diplomacy among sovereign states. Therefore, in addition to the president as the highest diplomatic decision-making head, the main body of China's diplomatic leaders since the 1990s should also include the premier of the State Council. Other leaders of the party and state "all obey and serve the two leaders in foreign affairs, playing a supporting role".[8] The main body of the summit diplomacy mentioned in this paper is mainly the heads of state or government of China and CEEC, including the representatives of heads of state or government under special circumstances.

Regarding the purpose, form, and content of summit diplomacy, some scholars define summit diplomacy as "a meeting held by political leaders for official purposes", and therefore does not include purely private activities of leaders.[9] Summit diplomacy is a meeting held by heads of state or government for diplomatic or propaganda purposes, and such meetings are divided into ad hoc summits and serial summits according to frequency.[10] Furthermore, there is a trend that summit diplomacy should be distinguished from other forms of direct personal diplomacy between political leaders, such as correspondence, telephone conversations, or video conversations.[11]

However, in the practice of contemporary summit diplomacy, there are not only ceremonial official activities but also eclectic private exchanges. There are both direct diplomatic negotiations and political performances. But it is often hard to tell whether they are motivated more by official or semi-official purposes, by diplomacy itself, or by propaganda. In the view of some Chinese domestic scholars, although the visit and meeting of the heads of state is the most important channel of the summit diplomacy, the correspondence and telephone call of the heads of state, the diplomacy of a special envoy, the declaration or statement of the heads of state are also important forms of the heads of state diplomacy.[12] Therefore, in addition to the purely ceremonial greetings and letters, the form and content of the summit diplomacy between the heads of China and the CEEC discussed in this paper are not limited to the visits and meetings of the heads of state.

\subsection{Progress and Characteristics of China- CEEC Summit Diplomacy in the New Era}

The "16 + 1" Summit held in Warsaw in April 2012 not only marked a new era in China-CEEC relations but also opened a new chapter in the summit diplomacy between the heads of state of China and CEEC. On the whole, the summit diplomacy between China and CEEC has promoted the "16 + 1" Cooperation and at the same time promote bilateral relations between China and CEEC. It can be said that the progress is remarkable and the characteristics are distinct.

\subsubsection{Feature 1: Institutionalizing the "16 +1 "Summit at the Prime Ministerial Level}

In April 2012, when Wen Jiabao, then Premier of the State Council of China, delivered a speech at the 2nd China-CEEC Economic and Trade Forum in Warsaw, he clearly stated that "we need to improve our cooperation mechanism. It is necessary for the two sides to continue holding economic and trade forums and hold leaders' meetings".[13] The following year, the "16 + 1" Summit was held, passing the " Bucharest Guidelines for Cooperation between China and Central and Eastern European Countries", which formally decided to "hold the 16 +1 Summit every year to review the achievements and chart the course for cooperation".[14] Since 2014 , the cooperation outlines adopted at each "16 +1 " Summit have been confirmed in written form the host of the next "16+1" Summit. From 2012, the "16+1" Summit has been held in turn for eight times. At present, the leaders attending the "16+1" Summit are basically heads of government (prime ministers or chairmen of the Council of Ministers), with occasional heads of state (Polish President Duda paid a state visit to China in November 2015 and attended the Summit) or representatives of heads of state such as speakers of parliament, deputy prime ministers and foreign ministers.

\subsubsection{Feature 2: Diversifying the Forms of Summit Diplomacy}

In addition to the institutionalized multilateral "16 + 1" Summit, the bilateral diplomacy between China and CEEC has been quite active since 2012, taking a variety of forms. First, the leaders of China and CEEC held bilateral meetings on the sidelines of the "16 + 1" Summit. Except for a few rare cases, during each "16+1" Summit, the Premier of the 
State Council of China will try his best to arrange bilateral meetings with leaders of every CEEC (including representatives of the leaders). In fact, the bilateral diplomatic activities of the multilateral diplomatic occasions of the heads of state are becoming more and more institutionalized. Second, the Chinese President or Premier of the State Council conducted bilateral summit diplomacy with leaders of some CEEC on other multilateral diplomatic occasions. For example, in 2015 and 2017, President Xi Jinping met in Beijing with leaders of CEEC such as Bosnia and Herzegovina, the Czech Republic, Serbia, Poland, and Hungary who came to China for the commemoration of the 70th anniversary of the victory of the Chinese People's War of Resistance against Japanese Aggression and the World Anti-Fascist War and the One Belt And One Road Forum for International Cooperation. In November 2018, President Xi met with heads of state from Hungary, the Czech Republic, Lithuania, and other CEEC who attended the first China International Import Expo in Shanghai. Since 2012, the Premier of the State Council of China has met with the heads of CEEC such as Bulgaria, Latvia, and Romania during the three ASEM meetings. Third, China and CEEC have actively conducted various forms of heads of state visits. Since 2012, China has exchanged official visits with the Czech Republic, Serbia, Poland, Romania, Hungary, and other CEEC. In addition to participating in the aforementioned major multilateral diplomatic events and attending the fourth "16 + 1" Summit in China, the heads of CEEC such as Albania, Bulgaria, Latvia, Lithuania, Macedonia, Montenegro, etc. have also repeatedly informally visited China and attended various events such as the Summer Davos Forum, the China-CEEC Local Leaders' Meeting, and the Youth Olympic Games and other activities.

\subsection{China and the Czech Republic from the Perspective of Summit Diplomacy: High-level Exchanges of Visits and Meetings Are Active, and Political Mutual Trust Continues to Increase}

The China-CEEC Cooperation Mechanism established in 2012 has become an important platform for China and CEEC to conduct transregional and multilateral cooperation. It has laid down a new framework for the development of mutually beneficial and win-win cooperation between China and CEEC and expanded the converging interests of the two sides. Under this cooperation mechanism, China-Czech relations have further developed in a sound and steady manner. In November 2015, China and the Czech Republic signed a Memorandum of Understanding to jointly promote the Belt and Road construction. In March 2016, China and the Czech Republic established a strategic partnership, ushering in a new era of bilateral relations.

To be specific, the active high-level visits and meetings between China and the Czech Republic since 2012 have played a leading role in promoting the development of bilateral relations. Major bilateral visits include:

In April 2012, Chinese Premier Wen Jiabao held a bilateral meeting with Czech Prime Minister Petr Nečas on the sidelines of the China-CEEC Summit in Warsaw. In November of the same year, Premier Wen Jiabao of the State Council exchanged greetings with Czech President Vaclav Klaus during his attendance at the 9th Asia-Europe Meeting (ASEM) summit in Vientiane.

In November 2013, Chinese Premier Li Keqiang of the State Council held a bilateral meeting with Czech Prime Minister Jiří Rusnok during his attendance at the China-CEEC Leaders' Meeting in Bucharest. Also in November 2013, Vice Foreign Minister Song Tao attended the first "China Investment Forum" in the Czech Republic and he met with Czech President Miloš Zeman, Prime Minister Jiří Rusnok, Minister of Foreign Affairs Jan Kohout, and other dignitaries from the Czech side during the forum.[15]

In February 2014, Chinese President Xi Jinping held a bilateral meeting with Czech President Milos Zeman on the sidelines of the Sochi Winter Olympics. Czech President Milos Zeman paid a state visit to China. President Xi Jinping and Premier Li Keqiang met with him respectively in October this year. In December of the same year, Chiese Premier Li Keqiang held a bilateral meeting with Czech Prime Minister Sobotka on the sidelines of the Third China-CEEC Summit in Belgrade.

In June 2015, Chinese Vice Premier Liu Yandong of the State Council went to the Czech Republic to attend the first China-CEEC Health Ministers' Forum. During the Forum, she met and held talks respectively with Czech President Miloš Zeman, Prime Minister Sobotka, and Chairman of the House of Representatives of the Czech Parliament Jan Hamáček. In September of the same year, Czech President Miloš Zeman was invited to Beijing to attend the commemoration of the 70th 
anniversary of the victory of the Chinese People's War of Resistance against Japanese Aggression and the World Anti-Fascist War. Xi Jinping held a bilateral meeting with Czech President Zeman. In November 2015, Prime Minister Sobotka of the Czech Republic came to China to attend the Fourth Summit of China and CEEC and paid an official visit to China. President Xi Jinping and Premier Li Keqiang met and talked with him respectively.

In 2016, the leaders of the Czech Republic and China visited and met frequently. The most important one is Chinese President Xi Jinping's visit to the Czech Republic in March, which is the first visit by a top Chinese leader to the Czech Republic since the two countries established diplomatic ties 67 years ago. It is also an important symbol of the peak of bilateral relations. The leaders of the two countries made strategic plans for bilateral relations. In this year, China-Czech relations were established as a strategic partnership. China-Czech relations "have entered the best period of growing from spring to summer."[16] In November of the same year, during the Fifth "16+1" Summit of CEEC and China, the government representative of the Czech Republic and government representatives of the People's Republic of China signed a plan of bilateral cooperation within the framework of the Silk Road initiative, which "stipulates the priorities of cooperation for both countries for the coming period, in key sectors such as infrastructure, investments, science, research and development finance, transport and logistics, healthcare, civil aviation, agriculture, tourism and more." The Czech Republic aims to become "a transport and logistics hub between China and the region of central, eastern and south-eastern Europe, and a center for Chinese financial institutions in the region."[17] The Czech government aims to "pursue intensive cooperation in the further development of CzechChinese relations and fulfill the strategic partnership between both countries". [18]

In general, at the previous China-CEEC summits, the prime ministers of the two countries held bilateral meetings on deepening bilateral relations and cooperation in various fields. From 2014 to 2019, Czech President Miloš Zeman visited China five times, which is the highest number of visits by the head of state of CEEC in recent years. Czech Prime Minister Bohuslav Sobotka visited China twice in November 2015 and June 2016 to attend the 4th China-CEEC Summit and the 3rd China-CEEC Local Leaders' Meeting respectively. The active high-level exchange of visits between the two countries has further consolidated the political foundation for the development of bilateral relations. In particular, the heads of state of the two countries have reached an important consensus on the development of bilateral relations in the new era and the joint construction of the "Belt and Road", which is beneficial to enhancing political mutual trust and deepening pragmatic cooperation between the two countries.

\section{CHINA AND THE CZECH REPUBLIC FROM THE PERSPECTIVE OF CHINA'S OVERALL COOPERATIVE DIPLOMACY (CHINA-CEEC COOPERATION)}

\subsection{China's Overall Cooperative Diplomacy and Its Basic Features}

Since the beginning of the 21 st century, with the increase of China's comprehensive national strength and international influence, profound changes have taken place in China's diplomatic approach. Among them, such overall cooperation mechanisms as the Forum on China-Africa Cooperation Forum (established in 2000), China-Arab States Cooperation Forum (established in 2004), ChinaCEEC Cooperation (established in 2012) and China-CELAC Forum (established in 2015) have attracted particular attention and aroused great international response. Combined with the partnerships and cooperation mechanisms established with the European Union (founded in 1998) and ASEAN (founded in 1996), China's diplomacy has initially put in place an overall cooperation framework covering major regions in the world.

COCD has its own characteristics. This diplomatic form is an increasingly common mode of cooperation in China's foreign exchanges in recent years. Its basic features are as follows:

First, China does not carry out reciprocal exchanges with a single sovereign state, but with a regional organization or group of countries that including multiple countries, which is manifested as one-to-multilateral exchanges. The relations between States in a regional organization or group of States acting as partners are equal and multilateral in nature and are governed and defined by the constitution of that organization. However, their exchanges with China are based on a collective identity, which constitutes reciprocal 
relations with China, thus forming a hybrid bilateral-multilateral pattern.

Second, the degree of institutionalization of overall cooperative diplomacy is relatively low. Its cooperation depends on the existence of the common interests of both sides, which belongs to the category of pragmatic cooperation and is different from functional international organizations. Although there is a secretariat, it is limited to dealing with transactional issues and does not generally have the nature of a permanent international organization. The convening of the forum depends on the political will of the top leaders of both sides.

Third, the role of overall cooperative diplomacy is not to replace bilateral cooperation between China and relevant countries, but to solve the problems of exchange efficiency, practical reciprocity, and effective communication between great power and small states. At the same time, the overall cooperative diplomacy can consider the scale efficiency of economic cooperation. In other words, it provides a stable expectation and institutional framework for bilateral exchanges, which in many ways helps reduce transaction costs, and more effectively promotes cooperation between China and related regions or national groups.

\subsection{Special Case in the Overall Diplomatic Cooperation: China-CEEC Cooperation}

The overall cooperation between China and CEEC is a special case in CODC that China has established. China-CEEC Cooperation is a kind of sub-regional cooperation. It refers to the comprehensive cooperative diplomacy conducted through the "16+1" model, with China on the one side and the 16 CEEC on the other since the summit of leaders of China and CEEC was launched in April 2012. In 2019, as Greece officially joined the "16 + 1" Cooperation mechanism, the mechanism was renamed "17 +1" Cooperation. Since the establishment of ChinaCEEC cooperation, this special cooperation within the overall framework of China-EU relations has greatly promoted the bilateral cooperation between China and CEEC.

As sub-regional cooperation, China-CEEC cooperation basically conforms to the concept of COCD, but it has its particularity. Its particularity lies in that, although CEEC have the initiative to develop relations with China and are regarded as a whole in their cooperation, these countries do not constitute a regional international organization with an independent identity, but a sub-regional group radiated by the space of the EU system. This means that the cooperation between China and Central and Eastern Europe is not only a simple "17+1" largescale bilateral cooperation but also means that it is inseparable from the overall relations between China and Europe. Therefore, it is necessary to properly deal with the balance between China and the EU level and between China and the developed countries in Western Europe.

In fact, cooperation between China and CEEC has always been guided by the principle of better complementing the overall development of ChinaEU relations. At the 5th China-CEEC Summit in 2016, the Riga Declaration was issued. The Riga Guidelines for Cooperation between China and CEEC highlighted that the "participants reaffirmed the intention to forge an efficient, practical and lasting ' $16+1$ ' Cooperation, to build a partnership featuring openness, inclusiveness, and mutual benefit, as well as to develop synergies between ' $16+1$ ' Cooperation and the EU-China Comprehensive Strategic Partnership, including through the EU-China Connectivity Platform."[19] The cooperation is an integral part and a useful supplement to China-EU cooperation, which is conducive to the balanced development of Europe and European integration. [20] In other words, the "17+1" Cooperation is an important part of the China-EU comprehensive strategic partnership and an important innovation in China-EU friendly cooperation. This is China's accurate positioning of the China-CEEC cooperation mechanism and the overall cooperation relations between China and Europe.

\subsection{China and the Czech Republic in China-CEEC Cooperation: Bilateral Pragmatic Cooperation in Economy, Trade, and Investment Has Been Continuously Deepened}

Against the backdrop of the China-EU Comprehensive Strategic Partnership and the deepening China-CEEC cooperation, China-Czech economic and trade relations have made remarkable progress. In 2013, China and the 16 CEEC jointly issued the "Bucharest Guidelines for Cooperation between China and Central and Eastern European Countries", which made the China-CEEC cooperation more detailed and more operational. In the years that followed, cooperation between the 
Czech Republic and China has been actively promoted within this framework. Since then, China and the Czech Republic have signed the "Memorandum of Understanding on Jointly Promoting the Construction of the Silk Road Economic Belt and the 21st Century Maritime Silk Road"[21], "Bilateral Cooperation Plan under the Framework of the Belt and Road Initiative"[22] and other cooperation documents. On this basis, China and the Czech Republic have deepened practical cooperation and strengthened cooperation in various fields such as infrastructure construction, investment, industry and trade, energy resources, scientific research, and finance. The Czech government also listed China as a key new market for development in its Export Strategy of the Czech Republic 2012 - 2020.[23] According to this Export Strategy, "the Czech goal is to increase the total export volume of services by $20 \%$ by 2020 , particularly services with high added value (such as in information and communication technology, creative industry, consulting, science and research services or tourism). This provides further potential for Czech exporters to enter the Chinese market."[24] Besides this, the two countries are working on the connection between the "Belt And Road" initiative and the Czech Industry 4.0, which also indicates great prospects for future cooperation.

The bilateral trade between China and the Czech Republic has increased significantly. The Czech Republic is China's second-largest trading partner in Central and Eastern Europe, and China is the Czech Republic's largest trading partner among non-EU countries. According to data from the Ministry of Commerce of China, the bilateral trade volume between the two countries has grown rapidly, from $\$ 8.73$ billion in 2012 to $\$ 10.98$ billion in 2014, exceeding $\$ 10$ billion for the first time, up 16.2 percent year on year. Since then, the bilateral trade volume between China and the Czech Republic has continued to grow, surpassing US $\$ 10$ billion for five consecutive years. In 2019, the bilateral trade volume doubled from 2012 to US\$17.59 billion.[25] According to Czech statistics, the total bilateral trade between China and the Czech Republic in the first nine months of 2020 was US\$22.79 billion, up by $9.6 \%$ year on year.[26]

Two-way investment has been active and Chinese investment in the Czech Republic has been on the rise. China's investment in the Czech Republic showed a spurt in the early stage of China-CEEC cooperation, with the total investment increasing continuously from less than US\$300 million at the end of 2013. As of March 2020,
China's direct investment in the Czech Republic has accumulated to US\$1.81 billion. The turnover of Chinese contracted projects in the Czech Republic reached US\$620 million. Czech companies have invested a total of 506 projects in China, with an actual investment of 310 million US dollars from the Czech side.[27] The number of Chinese enterprises in the Czech Republic has increased from a few in 2013 to nearly 50. In addition to traditional manufacturing such as automobiles, machinery, home appliances, and chemicals, Chinese enterprises' investment in the Czech Republic also covers emerging fields such as general aviation, information technology, new energy, high-speed rail, e-commerce, and tourism.[28]

\section{CHINA AND THE CZECH REPUBLIC: ON THE LONG ROAD TO A REAL STRATEGIC PARTNERSHIP}

In the new era, the relations between China and the Czech Republic have made considerable progress from the perspective of China's summit diplomacy with CEEC and COCD in Central and Eastern Europe. On the whole, summit diplomacy enhances mutual political trust between the two countries, and the "17+1" overall cooperation promotes bilateral economic and trade development. But in the same way, these diplomatic explorations in Central and Eastern Europe have their own shortcomings and uncertainties, which also bring challenges and thinking to the development of relations between China and CEEC.

On one side, as far as summit diplomacy is concerned, while summit diplomacy has played a leading and promoting role in the development of relations between countries, there is also uncertainty about how to assess the effectiveness of summit diplomacy. Taking the escalation of bilateral relations identified during the summit visits and talks as an example, "if the strategic partnership cannot be put into practice and the 'strategic' areas of bilateral relations are not clearly planned, ...... it can only reflect the 'retreat' component of China's foreign policy in developing bilateral relations and is not conducive to the effective promotion of China's relations with European countries, including Central and Eastern European countries".[29]

Moreover, in the case of China and the Czech Republic, despite the strong willingness to engage in friendly exchanges at the government level, there 
are still opposition voices in the Czech Republic to the development of Czech-China relations. The issue of Tibet in bilateral relations and the issue of "anti-China policy of the previous government under the banner of human rights for a long time"[30] remain, which also have impacts on the effectiveness of summit diplomacy.

In fact, the risks or potential dangers of summit diplomacy, such as the limitations of personalized diplomacy, the severity of misjudgments by leaders, and the repetition of policies after the change of heads of state, are indeed worth noting. For example, the diplomacy between China and the Czech Republic has risen sharply in recent years. This is largely due to the strong support of the Social Democratic Party, which dominates the Czech ruling coalition, and President Zeman, who was the chairman of the party. However, if there would be major changes in the Czech political situation, the prospects of the strategic partnership between the two countries may be variable, and summit diplomacy would inevitably be affected.[31] In short, to make relations between CEEC and China stable, it should not only see the achievements of summit diplomacy but also recognize the shortcomings and potential dangers of summit diplomacy. So that both parties can sum up their experience in time and prevent risks.

On the other side, from the perspective of "17+1" overall cooperation diplomacy, a special type of COCD, it also faces challenges and opportunities. First, unlike in the overall cooperation between China and other regional organizations or international groups, multilateral consultations within the partners play an important role. It can reduce or even prevent internal competition in cooperation with China, form a unified position and consensus with China, make it easier to reach agreement in large-scale bilateral negotiations, and improve the efficiency of negotiations. As for "17+1" Cooperation, since the degree of cooperation between CEEC and China cannot be exactly the same, and no country can negotiate on behalf of the 17 countries as a whole, this requires China to spend more time and energy in the process of multilateral coordination and maintain the necessary balance between the 17 countries. Second, in the process of developing China-CEEC relations, the major EU countries and EU institutions must also be fully considered. The $\mathrm{EU}$ is the most integrated regional cooperation organization in the world today, and the "17+1" Cooperation has artificially demarcation of a platform for subregional cooperation within and across the EU, which can easily arouse the concerns of the EU countries about China's intentions and motives to some extent. In this regard, it is very necessary for "17+1" Cooperation to achieve better results by increasing openness and transparency of cooperation and properly handling the division of labor and cooperation at three different levels of exchanges: regional, sub-regional and national.

\section{CONCLUSION}

Relations between China and the Czech Republic, similar to those of most Chinese and CEEC, have experienced a tortuous development path: from the ups and downs of relations with the Soviet Union to the differences and alienations caused by institutional and ideological differences to the institutional COCD in the new era, which not only reflects the dramatic changes in the international pattern and the theme of the times but also shows the transformation of China's diplomatic philosophy and development with the countries of the region.

At present, the relations between China and the Czech Republic under the framework of ChinaCEEC cooperation and summit diplomacy have both embraced opportunities and faced challenges. On one hand, the bilateral relations between China and the Czech Republic have made considerable progress: Summit diplomacy has promoted political mutual trust between China and CEEC, enhanced mutual understanding and people-to-people friendship between China and CEEC, and promoted China-Czech bilateral relations to the level of strategic partnership; In the process of "17+1" Cooperation of COCD, the Czech Republic has become China's second-largest trading partner in Central and Eastern Europe, while China is the largest trading partner of the Czech Republic among non-EU countries. The two countries are gradually deepening pragmatic cooperation, and the areas of cooperation are gradually covering political, economic, and cultural fields. On the other hand, doubts from the European Union and major Western powers, the changing internal political situation of CEEC, the pressure to pursue the speed and effectiveness of economic cooperation, and the negative public opinion leftover from history are the main challenges facing relations between CEEC and China. Only by placing the China-CEEC cooperation under the COCD mechanism, attaching importance to the particularity of CEEC, and increasing the study and 
participation in sub-regional cooperation, can the lasting development of this mechanism be realized.

In fact, China and the EU have recently released more positive signals for cooperation between the two sides: for example, in 2019, the EU has participated in the "17+1" cooperative framework as an observer, and at the end of December 2020, China and the EU wrapped up the negotiations on the Comprehensive Agreement on Investment after seven years. The completion of the EU-China Comprehensive Agreement on Investment negotiations is a big plus for both European and Chinese enterprises, reflecting the trend towards more multilateralism and free trade. "China-CEEC cooperation is showing less and less Central and Eastern European features, and more and more features distinctive to Europe."[32] In the context of the COVID-19 epidemic in 2020, China still was the "main partner for the EU. This result was due to an increase of imports $(+5.6 \%)$ and exports (+2.2\%)."[33] According to statistics, China for the first time overtook the United States as the EU's largest trading partner, and China is the only one of the EU's top ten trading partners for goods to achieve two-way growth in trade, which fully shows the strength and potential of China-EU economic and trade relations.

In the long run, there is huge potential for cooperation between China and CEEC, including China and the Czech Republic. The Czech Republic and China should continue to make full use of the "17 + 1" Cooperation, actively carry out summit diplomacy, and gradually promote the development of the strategic partnership between the two countries.

\section{AUTHORS' CONTRIBUTIONS}

This paper is independently completed by Siyang Liu.

\section{REFERENCES}

[1] Barston, R. P. Modern Diplomacy (2nd Edition). New York: Addison Wesley Longman Inc. 1997.

[2] Zhao, Kejin. Introduction to Non-traditional Diplomacy. Beijing: Peking University Press. 2015.

[3] Hu, Yong. "The Legal Status and Practical Space of China's Summit Diplomacy", in International Responsibilities and Great Power
Strategy, ed. Zhongqi Pan, Shanghai: Shanghai People's Publishing House, 2008.

[4] Long, Jing. "Relations between China and Central and Eastern European Countries: Development, Challenges and Countermeasures", International Studies 5(2014): 37-50.

[5] Zhu, Xiaozhong. "China-CEEC Cooperation: Characteristics and Improvement Directions", International Studies, 3(2017):41-50.

[6] Dunn, David Hastings and Lock - Pullan, Richard. "Diplomatic Summitry" , in The Sage Handbook of Diplomacy, ed. Costas M. Constantinou et al., London: Sage Publications, 2016.

[7] Plischke, Elmer. Diplomat in Chief: The President at the Summit , New York: Praeger, 1986.

[8] Zhao, Kejin. The Transformation and Position of Contemporary China's Diplomatic Institutions, Beijing: Current Affairs Press, 2012.

[9] Dunn, David Hastings. "What is Summitry," In Diplomacy at the Highest Level: the Evolution of International Summitry, David H. Dunn ed. Hampshire: Palgrave Macmillan, 1996.

[10] Berridge, G. R . And James, Alan. A Dictionary of Diplomacy, New York: Palgrave Macmillan, 2003.

[11] Melissen, Jan. Summit Diplomacy Coming of Age, Discussion Papers in Diplomacy, Netherlands Institute of International Relations "Clingendael", ISSN 1569-2981, 2003.

[12] Zhao, Kejin. Principles of Diplomacy, Shanghai: Shanghai Education Publishing House, 2011.

[13] Cooperation between China and Central and Eastern European Countries. "Speech by Premier Wen Jiabao at the Second ChinaCentral and Eastern European Countries Economic and Trade Forum." accessed November 1, 2013. http: / /www. china - ceec. org /chn /ldrhw /2012hs/ hdxw /t1409869. htm. 
[14] Cooperation between China and Central and Eastern European Countries. "Bucharest Guidelines for Cooperation between China and Central and Eastern European Countries." accessed January 26, 2015. http: / /www. china - ceec. org /chn /ldrhw /2013bjlst / hdxw /t1409845. htm.

[15] Embassy of the People's Republic of China in the United Kingdom of Great Britain and Northern Ireland. "Vice Foreign Minister Song Tao Attends China Investment Forum in the Czech Republic". accessed November 14 2013. http://www.chineseembassy.org.uk/eng/zgyw/t1100624.htm.

[16] Xinhua News Agency. "Plant trees into forests and grow in spring and summer : A record of President Xi Jinping's state visit to the Czech Republic". accessed April 12016. http://www.xinhuanet.com//world/201604/01/c_128853936.htm.

[17] Government of the Czech Republic. "The Czech Republic Continues To Intensify Relations With China, Plan For Bilateral Cooperation Between Both Companies Adopted At 16+1 Summit". accessed November $\quad 5016$. https://www.vlada.cz/en/mediacentrum/aktualne/the-czech-republiccontinues-to-intensify-relations-with-china-plan-for-bilateral-cooperation-between-bothcompanies-adopted-at-161-summit-150713/.

[18] Government of the Czech Republic. "Prime Minister Sobotka Pursues Further Development Of Czech-Chinese Trade and Tourism Relations At The 16+1 Summit In Riga". accessed November 5 2016. https://www.vlada.cz/en/mediacentrum/aktualne/prime-minister-sobotkapursues-further-development-of-czechchinese-trade-and-tourism-relations-at-the161-summit-in-riga-150715/.

[19] Ministry of Foreign Affairs of the People's Republic of China. "The Riga Guidelines for Cooperation between China and Central and Eastern European Countries". accessed November $\quad 6 \quad 2016$. https://www.fmprc.gov.cn/web/gjhdq_676201 /gj_676203/oz_678770/1206_679282/1207_6 79294/t1413179.shtml.
[20] Xinhua News Agency. "Chinese Premier Li Keqiang's speech at the Fifth China-CEEC Summit". accessed November 62016. http://www.xinhuanet.com/world/201611/06/c_1119859069.htm.

[21] Ministry of Commerce of the People's Republic of China. "List of achievements of China-CEEC cooperation in five years". $\begin{array}{lll}\text { accessed November } 28 & 2817 .\end{array}$ http://ozs.mofcom.gov.cn/article/hzcg/201712/ 20171202681864.shtml.

[22] National Development and Reform Commission of the People's Republic of China. "The Governments of China and the Czech Republic Signed the 'Bilateral Cooperation Plan under the Framework of the Belt and Road Initiative"', accessed November 7 2016, https://www.ndrc.gov.cn/fzggw/jgsj/kfs/sjdt/2 01611/t20161107_1086149.html.

[23] Ministry of Industry and Trade of the Czech Republic. "Export Strategy of the Czech Republic 2012-2020". accessed April 262012. https://mpo.cz/en/guidepost/ministry/minister/ export-strategy-of-the-czech-republic-2012--2020--104211/.

[24] Castro, Tereza De. and Stuchlikova,Zuzana. "China-V4 Trade Relations-A Czech Perspective." Paper presented at Current Trades and Perspectives in Development China-V4 Trade and Investment Conference of International Scientific Conference, Bratislava, March 12 - 14, 2014.

[25] Ministry of Commerce of the People's Republic of China. "Guide to Foreign Investment Cooperation, Czech Republic". accessed May 2020. http://fec.mofcom.gov.cn/article/gbdqzn/index .shtml\#,http://www.mofcom.gov.cn/dl/gbdqzn /upload/jieke.pdf

[26] Economic and Commercial Office of the Embassy of the People's Republic of China in the Czech Republic. "Statistics of Sino-Czech bilateral trade from January to September 2020 (Czech statistics)". accessed November 11 2020. http://cz.mofcom.gov.cn/article/tjsj/202011/20 201103014683.shtml.

[27] Ministry of Foreign Affairs of the People's Republic of China. "China-Czech Relations", 
accessed September 2020. https://www.fmprc.gov.cn/web/gjhdq_676201 /gj_676203/oz_678770/1206_679282/sbgx_67 9286/.

[28] People's Daily. "Improve the level of production line intelligence and encourage local employees to participate in management: Made in China in the Czech Republic". accessed December 232017. http://world.people.com.cn/n1/2017/1213/c10 02-29703279.html.

[29] Zhu, Xiaozhong. editor et al., 20 Years of Transition in Central and Eastern Europe. Beijing: Social Sciences Academic Press China, 2013.

[30] Liu, Zuokui. "The Change of Czech Foreign Policy and the Prospect of Sino-Czech Relations", Contemporary world 5(2016): 2830 .

[31] Jiang, Li. "China-Czech Relations Boosted by the Belt and Road Initiative", in The Belt and Road Construction and Development Report (2017), Ed. Li, Yongquan. Beijing: Social Sciences Academic Press China, 2017.

[32] Kong Hanbing. "Time to upgrade cooperation with CEE nations." Chinadaily, February 9, 2021. Accessed February 9, 2021. http://europe.chinadaily.com.cn/a/202102/09/ WS6021f47ba31024ad0baa8439.htm.

[33] BBC. "China overtakes US as EU's biggest trading partner." Accessed February 17, 2021. https://www.bbc.com/news/business-

56093378. 